\title{
Microcavity arrays as an in vitro model system of the bone marrow niche for hematopoietic stem cells
}

Citation for published version (APA):

Wuchter, P., Saffrich, R., Giselbrecht, S., Nies, C., Lorig, H., Kolb, S., Ho, A. D., \& Gottwald, E. (2016). Microcavity arrays as an in vitro model system of the bone marrow niche for hematopoietic stem cells. Cell and Tissue Research, 364(3), 573-584. https://doi.org/10.1007/s00441-015-2348-8

Document status and date:

Published: 01/06/2016

DOI:

10.1007/s00441-015-2348-8

Document Version:

Publisher's PDF, also known as Version of record

Document license:

Taverne

Please check the document version of this publication:

- A submitted manuscript is the version of the article upon submission and before peer-review. There can be important differences between the submitted version and the official published version of record.

People interested in the research are advised to contact the author for the final version of the publication, or visit the DOI to the publisher's website.

- The final author version and the galley proof are versions of the publication after peer review.

- The final published version features the final layout of the paper including the volume, issue and page numbers.

Link to publication

\footnotetext{
General rights rights.

- You may freely distribute the URL identifying the publication in the public portal. please follow below link for the End User Agreement:

www.umlib.nl/taverne-license

Take down policy

If you believe that this document breaches copyright please contact us at:

repository@maastrichtuniversity.nl

providing details and we will investigate your claim.
}

Copyright and moral rights for the publications made accessible in the public portal are retained by the authors and/or other copyright owners and it is a condition of accessing publications that users recognise and abide by the legal requirements associated with these

- Users may download and print one copy of any publication from the public portal for the purpose of private study or research.

- You may not further distribute the material or use it for any profit-making activity or commercial gain

If the publication is distributed under the terms of Article $25 \mathrm{fa}$ of the Dutch Copyright Act, indicated by the "Taverne" license above, 


\title{
Microcavity arrays as an in vitro model system of the bone marrow niche for hematopoietic stem cells
}

\author{
Patrick Wuchter $^{1,3}$ - Rainer Saffrich ${ }^{1,3}$ - Stefan Giselbrecht ${ }^{3,4}$ Cordula Nies $^{2,3}$. \\ Hanna Lorig ${ }^{2,3}$ - Stephanie Kolb ${ }^{2,3}$ • Anthony D. Ho ${ }^{1,3}$ - Eric Gottwald ${ }^{2,3}$
}

Received: 15 September 2015 / Accepted: 10 December 2015 / Published online: 30 January 2016

(C) Springer-Verlag Berlin Heidelberg 2015

\begin{abstract}
In previous studies human mesenchymal stromal cells (MSCs) maintained the "stemness" of human hematopoietic progenitor cells (HPCs) through direct cell-cell contact in two-dimensional co-culture systems. We establish a three-dimensional (3D) co-culture system based on a custom-made chip, the $3^{\mathrm{D}}$-KITChip, as an in vitro model system of the human hematopoietic stem cell niche. This array of up to 625 microcavities, with $300 \mu \mathrm{m}$ size in each orientation, was inserted into a microfluidic bioreactor. The microcavities of the $3^{\mathrm{D}}$-KITChip were inoculated with human bone marrow MSCs together with umbilical cord blood HPCs. MSCs used the microcavities as a scaffold to build a complex 3D mesh. HPCs were distributed three-dimensionally inside this MSC network and formed B-catenin- and N-cadherin-based intercellular junctions to the surrounding MSCs. Using $\mathrm{RT}^{2}$-PCR and western blots, we demonstrate that a proportion of HPCs maintained the expression of CD34 throughout a
\end{abstract}

Patrick Wuchter

patrick.wuchter@med.uni-heidelberg.de

Eric Gottwald

eric.gottwald@kit.edu

1 Department of Medicine V, Heidelberg University, 69120 Heidelberg, Germany

2 Institute for Biological Interfaces-5, Karlsruhe Institute of Technology (KIT), 76344Eggenstein-Leopoldshafen, Karlsruhe, Germany

3 HEiKA - Heidelberg Karlsruhe Research Partnership, Heidelberg University and Karlsruhe Institute of Technology, Heidelberg and Karlsruhe, Germany

4 Department of Complex Tissue Regeneration, MERLN Institute for Technology-Inspired Regenerative Medicine, Maastricht University, Maastricht, The Netherlands culture period of 14 days. In colony-forming unit assays, the hematopoietic stem cell plasticity remained similar after 14 days of bioreactor co-culture, whereas monolayer cocultures showed increasing signs of HPC differentiation and loss of stemness. These data support the notion that the 3D microenvironment created within the microcavity array preserves vital stem cell functions of HPCs more efficiently than conventional co-culture systems.

Keywords Hematopoietic progenitor cells · Mesenchymal stromal cells $\cdot$ Stem cell niche $\cdot$ Microcavity array $\cdot$ Bioreactor

\section{Introduction}

Many attempts have been made to develop in vitro systems that could promote maintenance and proliferation of hematopoietic stem cells. In 1976, Dexter et al. carried out experiments with a liquid culture system of femoral bone marrow cells from mice, which indicated the importance of co-culture conditions for the preservation of hematopoietic competence (Dexter et al. 1976; Dexter and Laijtha 1975). Since then, several approaches have been made to establish xenogeneic stromal cell lines for studying the regulation of hematopoietic stem cell proliferation and differentiation (Hunt et al. 1987; Kodama et al. 1986; Tsai et al. 1986; Whitlock et al. 1987). In humans, mesenchymal stromal cells (MSCs) represent one of the major cellular determinants of the bone marrow niche. It has been demonstrated that cellular interaction with the niche cells plays a significant role in the mobilization, homing and maintenance of stemness of hematopoietic progenitor cells (HPCs) (Ehninger and Trumpp 2011; Hanke et al. 2014; Jing et al. 2010; Lapidot and Kollet 2002; Levesque et al. 2010; Mendez-Ferrer et al. 2010; Schajnovitz et al. 2011; Wuchter et al. 2014). Direct cell-cell contacts that allow the 
formation of cadherin-/catenin-based junctional complexes appear to be among the major determinants of the maintenance of stem cell properties (Wein et al. 2010). In previous studies, human MSCs have been used as a feeder layer in various two-dimensional (2D) co-culture systems with human HPCs to examine the regulation of these stem cell functions (Christophis et al. 2011; Ludwig et al. 2014; Wagneret al. 2007b). However, 2D systems may not adequately reflect the in vivo situation, which motivated us to develop a $3 \mathrm{D}$ co-culture system using exclusively human primary cells as a more realistic in vitro model of the hematopoietic stem cell niche. These more organotypic in vitro models could improve our ability to address fundamental questions about the regulation of the native niche and allow the exploration of methods to manipulate the niche function for therapeutic purposes.

The $3^{\mathrm{D}}$-KITChip system (Fig. 1a, a') was developed by the Karlsruhe Institute of Technology (KIT) (Giselbrecht et al. 2006a; Gottwald et al. 2008). This system represents a unique microchip with defined microwell cavities for high-density three-dimensional (3D) cell culture applications. The system has previously been shown to support stem cell differentiation of retina stem cells (Rieke et al. 2008), primary human alveolar bone osteoblast differentiation (Altmann et al. 2014) and enhancement of organotypic behavior of liver cells (Gottwald et al. 2007a). Here, we present the development of a microfluidic 3D model system of the human hematopoietic stem cell niche and report its effects on HPC stem cell maintenance.

\section{Materials and methods}

\section{Chip design and manufacturing}

The $3^{\mathrm{D}}$-KITChips used for the experiments are the so-called $\mathrm{f}$ $3^{\mathrm{D}}$-KITChip and r-3 $3^{\mathrm{D}}$-KITChip (Fig. 1a, a'), two of the currently available variants of the $3^{\mathrm{D}}$-KITChip family (Gottwald et al. 2007a, b). Briefly, the manufacturing technique for the fchip type combines a microinjection molding/micro-hot embossing and a solvent welding step to attach a microperforated membrane to the back of the chip. The chip produced by this process is characterized by increased flexibility with regard to adjusting the material properties and the porosity of the bottom of the chip for customized cell culture applications. Prior to bonding, the residual layer of the molded chip was not just thinned down but was completely ablated,
Fig. 1 KITChip and bioreactor setup. a $\mathrm{f}-3^{\mathrm{D}}$-KITChip. a' $r-3^{\mathrm{D}}-$ KITChip. b Closed loop setup with bioreactor, medium reservoir and cassette pump. c Closed and opened bioreactors showing the perfusion flow scheme (c') and the superfusion flow scheme (c")
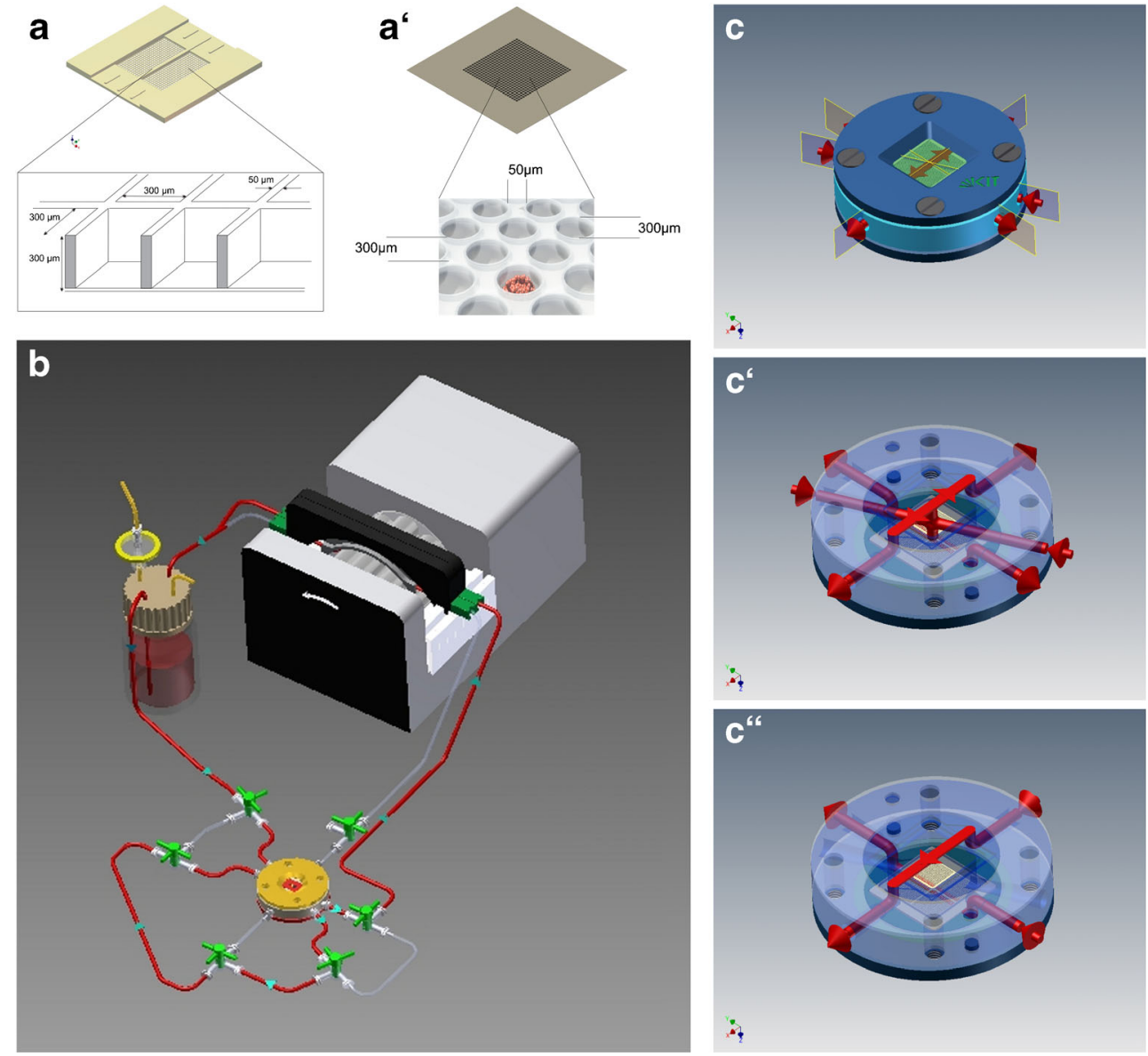
resulting in a chip with the back side open. The bonding process is a solvent welding process intended to yield joints without any additional or foreign substances (e.g., adhesives), which is advantageous for achieving a biocompatible product. Therefore, a computer-controlled semi-automated solvent welding apparatus was developed. This apparatus allows the joining of microperforated membranes and molded microstructured components in a batch process with cycle times of less than $10 \mathrm{~s}$. Four sets of microperforated membranes and molded components were simultaneously exposed to a gaseous solvent in a small, gas-tight chamber, before being pressed together. Subsequent evacuation of the chamber leads to a solvent-free permanent joint between the microperforated membrane and the microcavity array. The $\mathrm{r}$ chip is made by a microthermoforming technique, the socalled SMART process, developed by us (Giselbrecht et al. 2004, 2006b, 2008; Truckenmuller et al. 2008, 2011). Briefly, thin polymer films with a thickness of only $50 \mu \mathrm{m}$ are heated and pressed into a mold by applying appropriate pressure. Prior to microthermoforming, surface modifications onto the planar polymer film can be introduced leading to a translation of the surface modification from the planar state into the third dimension after thermoforming. In a post-process step, pores can be introduced into the polymer film leading to highly porous microcavities.

\section{Bioreactor setup}

The bioreactor for the housing of the $3^{\mathrm{D}}$-KITChip can support perfusion as well as superfusion flow schemes (Fig. 1c, c', c"). The closed loop setup (Fig. 1b) consisted in the $3^{\mathrm{D}}$ KITChip that was inserted into a bioreactor housing, a medium reservoir, a cassette pump and a gas mixing station (not shown). Several attempts have been made before to culture stem cells in scaffolds and microbioreactors with different ways of medium supply (Dang et al. 2014; de Peppo et al. 2014; Liu et al. 2013; O'Neill et al. 2013; Spiller et al. 2015). By applying the superfusion flow regime in our bioreactor system, with the fluid flowing in parallel to the surface of the tissue, the supply of nutrients and gases in the depth of microcavities is achieved by diffusion over both the top and bottom surfaces of the chip. In contrast, in the perfusion mode, the medium is flowing perpendicular to the surface of the tissue, i.e., through the porous bottom of the chip and the tissue of each microcavity. Pilot experiments indicated superfusion as a favorable setup for the co-culture of HPC/MSC (data not shown). Therefore, all experimental data presented in this study were generated by applying the superfusion flow regime at $400 \mu \mathrm{l} / \mathrm{min}$.

\section{Isolation of human hematopoietic progenitor cells}

Hematopoietic progenitor cells (HPCs) were isolated from umbilical cord blood after obtaining informed consent according to the guidelines approved by the Ethics Committee of the Medical Faculty of Heidelberg University. HPCs were isolated as described (Wein et al. 2010). Briefly, mononuclear cells (MNC) were isolated by density gradient centrifugation with the Ficoll-hypaque technique (Biochrom, Berlin, Germany). $\mathrm{CD} 34^{+}$cells were purified by positive selection with a monoclonal anti-CD34 antibody using magnetic microbeads on an affinity column with the AutoMACS system (all Miltenyi Biotec, Bergisch-Gladbach, Germany). Reanalysis of the isolated cells by flow cytometry revealed a purity of $>95 \% \mathrm{CD} 34^{+}$cells.

\section{Isolation of human mesenchymal stromal cells}

Human mesenchymal stromal cells (MSCs) were isolated from human bone marrow (BM) from healthy voluntary donors after obtaining informed written consent according to the guidelines approved by the Ethics Committee of the Medical Faculty of Heidelberg University. MSCs were isolated and expanded using standardized culture conditions (Wagner et al. 2005b). Briefly, bone marrow aspirates (10-30 ml) were collected in a syringe containing 10,000 IU heparin to prevent coagulation. The MNC fraction was isolated by density gradient centrifugation on Ficoll-Hypaque $\left(d=1.077 \mathrm{~g} / \mathrm{cm}^{3}\right.$; Biochrom) and seeded in tissue culture flasks at a density of $1 \times 10^{6}$ cells $/ \mathrm{cm}^{2}$ (Nunc ${ }^{\circledR}$-flasks with $75 \mathrm{~cm}^{2}$ area; Nalge Nunc, Naperville, IL, USA) for 2 days.

The MSCs were expanded in the commercially available Poietics Human Mesenchymal Stem Cell Basal Medium (PT3001; LONZA, Walkersville, MD, USA) following the manufacturer's instructions. For this step, 5,000 cells $/ \mathrm{cm}^{2}$ were plated in tissue flasks without any pre-coating. The culture medium was changed twice per week. After reaching $80 \%$ confluence, the MSCs were trypsinized, counted with a Neubauer counting chamber (Brand, Wertheim, Germany) and re-seeded at $10^{4}$ cells $/ \mathrm{cm}^{2}$ for further expansion. If not indicated otherwise, sub-confluent MSC feeder layers (70-80\%) of cells from passage 3 to 6 were used in this study. The capacity of the MSCs to differentiate into the osteogenic, adipogenic and chondrogenic lineages was confirmed. The intercellular connections and junctional complexes of these MSCs have been reported in detail (Wuchter et al. 2007).

For HPC/MSC co-culture experiments long-term bone marrow culture medium (LTBMC) was used, consisting of $75 \%$ Iscove's modified Dulbecco's medium (IMDM; Invitrogen, Karlsruhe, Germany), $12.5 \%$ FCS and $12.5 \%$ horse serum (both Stemcell Technologies, Vancouver, Canada), supplemented with $2 \mathrm{mM} \mathrm{L-glutamine,} 100 \mathrm{U} / \mathrm{ml}$ penicillin/streptomycin (Invitrogen) and $0.05 \%$ hydrocortisone 100 (Sigma-Aldrich, Munich, Germany). No cytokines were added to the culture medium. 


\section{Inoculation of the $3^{\mathrm{D}}$-KITChip}

Cells were mixed in suspension in a ratio of 3:2 $\left(3 \times 10^{5}\right.$ MSCs and $2 \times 10^{5}$ HPCs) and inoculated into the KITChip by manually applying a drop of $150 \mu \mathrm{l}$ single cell suspension on top of the microcavities. As 300,000 MSCs and 200,000 HPCs were inoculated per KITChip (with 625 microcavities), on average 480 MSCs and 320 HPCs were inoculated per microcavity, respectively. The chip was placed in an incubator for $2 \mathrm{~h}$ and subsequently mounted into the microbioreactor, allowing active nutrient and gas supply.

\section{Real-time RT-PCR}

The RNA concentration was determined using a Lab-on-aChip RNA6000 Nano Series II kit (Agilent Technologies, Waldbronn, Germany) that was run on an Agilent 2100 Bioanalyzer instrument (Agilent Technologies). The samples were diluted to a concentration of $0.4 \mu \mathrm{g} / \mu \mathrm{l}$ RNA and $2.5 \mu \mathrm{g}$ of total RNA from each sample was used for the reverse transcription. The reaction was performed using the Transcriptor High Fidelity cDNA synthesis kit (05081963001; Roche Diagnostics Deutschland, Mannheim, Germany) according to the manufacturer's instructions. Briefly, each $50-\mu$ l sample contained $10 \mu \mathrm{l} 5 \times \mathrm{RT}$ reaction buffer, $0.2 \mathrm{mM}$ of each deoxynucleotide triphosphate, $20 \mathrm{U}$ recombinant RNase inhibitor, $5 \mathrm{mM}$ dithiothreitol, $2.4 \mathrm{U}$ High-Fidelity reverse transcriptase and $2.5 \mu \mathrm{M}$ anchored oligo $\mathrm{d}(\mathrm{T})_{16}$. The mixes were incubated for $30 \mathrm{~min}$ at $45^{\circ} \mathrm{C}$, followed by $5 \mathrm{~min}$ at $85^{\circ} \mathrm{C}$ and then quickly chilled on ice. Real-time PCR was performed using the universal probe library (UPL) technique (Roche Applied Science, Mannheim, Germany). The UPL technique uses 8-9mer probes that are labeled with FAM at the 5'-end and with a dark quencher at the 3'-end (Roche Applied Science). The reactions were performed on a Rotor-Gene 3000 instrument (Qiagen, Hilden, Germany) in $25 \mu \mathrm{l}$ containing $0.25 \mu \mathrm{l}$ of a $10 \mu \mathrm{M}$ solution of the specific probe (Roche Applied Science), $1.6 \mu \mathrm{l}$ of a $10 \mathrm{mM}$ dNTP solution (Amersham Biosciences, Piscataway, NJ, USA), $4 \mu \mathrm{l}$ of a $12 \mu \mathrm{M}$ UPL-primer solution, $12.5 \mu \mathrm{l}$ of a $2 \times$ QuantiFast Probe PCR kit buffer (Qiagen) and $1 \mu \mathrm{l}$ cDNA. The reactions were amplified for 40 cycles under the following conditions: $95^{\circ} \mathrm{C}$ for $30 \mathrm{~s}, 60^{\circ} \mathrm{C}$ for $30 \mathrm{~s}$ and $72{ }^{\circ} \mathrm{C}$ for $30 \mathrm{~s}$. We analyzed the expression of the genes listed in Table 1 in a semiquantitative fashion using GAPDH as an internal standard.

\section{Colony-forming cell assay}

For the colony-forming cell assay, $300 \mu \mathrm{l}$ of a cell solution containing $2 \times 10^{4}$ cells (HPCs or HPCs + MSCs) was mixed with $3 \mathrm{ml}$ methylcellulose (R\&D Systems Wiesbaden, Germany) and vortexed. For each batch of HPCs, $2.5 \mathrm{ml}$ of cells were pipetted into a $35-\mathrm{mm}$ Petri dish in duplicate. Thus, the total number of inoculated cells was always the same, whereas the number of freshly isolated HPCs as control was intentionally higher than the HPC number in the co-culture

Table 1 Primers for $\mathrm{RT}^{2}$-PCR

\begin{tabular}{llll}
\hline Primer & Forward & Reverse & UPL-probe \\
\hline GAPDH & 5'-ctgacttcaacagcgacacc-3' & 5'-tgctgtagccaaattcgttgt-3' & $\# 25$ \\
CD7 & 5'-ggcggtgatctccttcct-3' & 5'-aattcttatcccgccacga-3' & $\# 23$ \\
CD14 & 5'-gttcggaagacttatcgaccat-3' & 5'-acaaggttctggcgtggt-3' & $\# 74$ \\
CD15 & 5'-gcgtgttggactacgagga-3' & 5'-cgactcgaagttcatccaaac-3' & $\# 19$ \\
CD33 & 5'-agtgaagacccacaggagga-3' & 5'-ggccatgtaacttggacttctt-3' & $\# 71$ \\
CD34 & 5'-tggagcaaaataagacctccag-3' & 5'-aaggagcagggagcatacc-3' & $\# 52$ \\
CD38 & 5'-cagaccgtaccttgcaacaa-3' & 5'-aggtcatcagcaaggtagcc-3' & $\# 65$ \\
CD44 & 5'-tcttcaacccaatctcacacc-3' & 5'-gctgaagcgttatactatgactgg-3' & $\# 4$ \\
CD90 & 5'-aggacgagggcacctacac-3' & 5'-gccctcacacttgaccagtt-3' & $\# 22$ \\
CD105 & 5'-ccactgcacttggcctaca-3' & 5'-gcccactcaaggatctgg-3' & $\# 60$ \\
CD166 & 5'-ggaggaatatggaatccaagg-3' & 5'-ctgaatttacagtataccatccaagg-3' & $\# 29$ \\
c-kit & 5'-cggctctgtctgcattgtt-3' & 5'-aacaggcacagctttgaagg-3' & $\# 79$ \\
Nestin & 5'-cgttggaacagaggttgga-3' & 5'-tgtaggccctgtttctctg-3' & $\# 51$ \\
p21 & 5'-cgaagtcagttccttgtggag-3' & 5'-catgggttctgacggacat-3' & $\# 82$ \\
SDF-1 & 5'-ccaaactgtgcccttcagat-3' & 5'-tggctgttgtgcttacttgttt-3' & $\# 80$ \\
Angpt-1 & 5'-gctaccatgctggagatagga-3' & 5'-tctcaagtcgagaagtttgatttagt-3' & $\# 75$ \\
IL-7 & 5'-tatgggcggtgagagctt-3' & 5'-aggggaggaagtccaaagata-3' & $\# 15$ \\
VCAM & 5'-tggaaaaaggaatccaggtg-3' & 5'-aactgaacacttgactgtgatcg-3' & $\# 75$ \\
SPP-1 & 5'-gagggcttggttgtcagc-3' & 5'-caattctcatggtagtgagttttcc-3' & $\# 18$ \\
CXCR4 & 5'-cctgcctggtattgtcatcc-3' & 5'-aggatgactgtggtcttgagg-3' & $\# 49$ \\
\hline & & & \\
\hline
\end{tabular}


assays to avoid any overestimation of the co-culture effect. The samples were analyzed for the formation of colonies or for RT-PCR experiments on days $0,7,14$ and 21, with or without bioreactor culture, respectively.

Cells were re-seeded on 24-well plates in serial dilutions from 1:100 to $1: 10^{6}$ in $200 \mathrm{ml}$ LTBMC medium. In each well, $500 \mathrm{ml}$ methylcellulose (HSC-CFU lite with Epo, Miltenyi Biotec) was added. The final analyses were performed on days 14 and 21, depending on the end-point assay.

\section{Western blot}

The cells were washed with PBS and the supernatant was aspirated. Cells were lysed by the addition of $50 \mu \mathrm{l}$ cell disruption buffer (Paris Kit; Life Technologies, Darmstadt, Germany) and the lysates were stored at $-80{ }^{\circ} \mathrm{C}$ until use. A maximum of $25 \mu \mathrm{l}$ sample and $25 \mu \mathrm{l}$ Laemmli buffer was heated to $95{ }^{\circ} \mathrm{C}$ for $5 \mathrm{~min}$, cooled on ice and centrifuged at $14,000 \mathrm{~g}$ for $5 \mathrm{~min}$. Next, $20-40 \mu \mathrm{g}$ total protein per sample was loaded onto a SDS-PAGE gel (10\% pre-cast gel, NuSep; PEQLAB, Erlangen, Germany) and run at $50 \mathrm{~mA}$ and $120 \mathrm{~V}$. Electrotransfer to PVDF membranes (Millipore, Schwabach, Germany) was accomplished using $300 \mathrm{~mA}$ and $70 \mathrm{~V}$ overnight at $4{ }^{\circ} \mathrm{C}$ in transfer buffer ( $25 \mathrm{mM}$ Tris, $192 \mathrm{mM}$ glycine, $10 \% \mathrm{MeOH})$. PVDF membranes were activated by wetting with methanol and were washed with $\mathrm{H}_{2} \mathrm{O}$ before transfer. After transfer, the membranes were incubated with blocking buffer (TBS $+0.2 \%$ Tween-20 (TBST) $+10 \% \mathrm{w} / \mathrm{v}$ non-fat dry milk) for $60 \mathrm{~min}$ at room temperature. The membranes were incubated for $2 \mathrm{~h}$ at room temperature with primary antibodies against CD34 (1:500,00 dilution, 2749-1; Epitomics, Burlingame, CA, USA), CD38 (Ab2577; Abcam, Cambridge, UK) and CD133, respectively (1:100; Miltenyi Biotec, Bergisch-Gladbach, Germany). After

\section{$\Delta \Delta \mathbf{C}_{\mathbf{t}}$ of $\mathrm{HSC} / \mathrm{MSC}$ co-culture under superfusion conditions $(400 \mu \mathrm{l} / \mathrm{min})$}

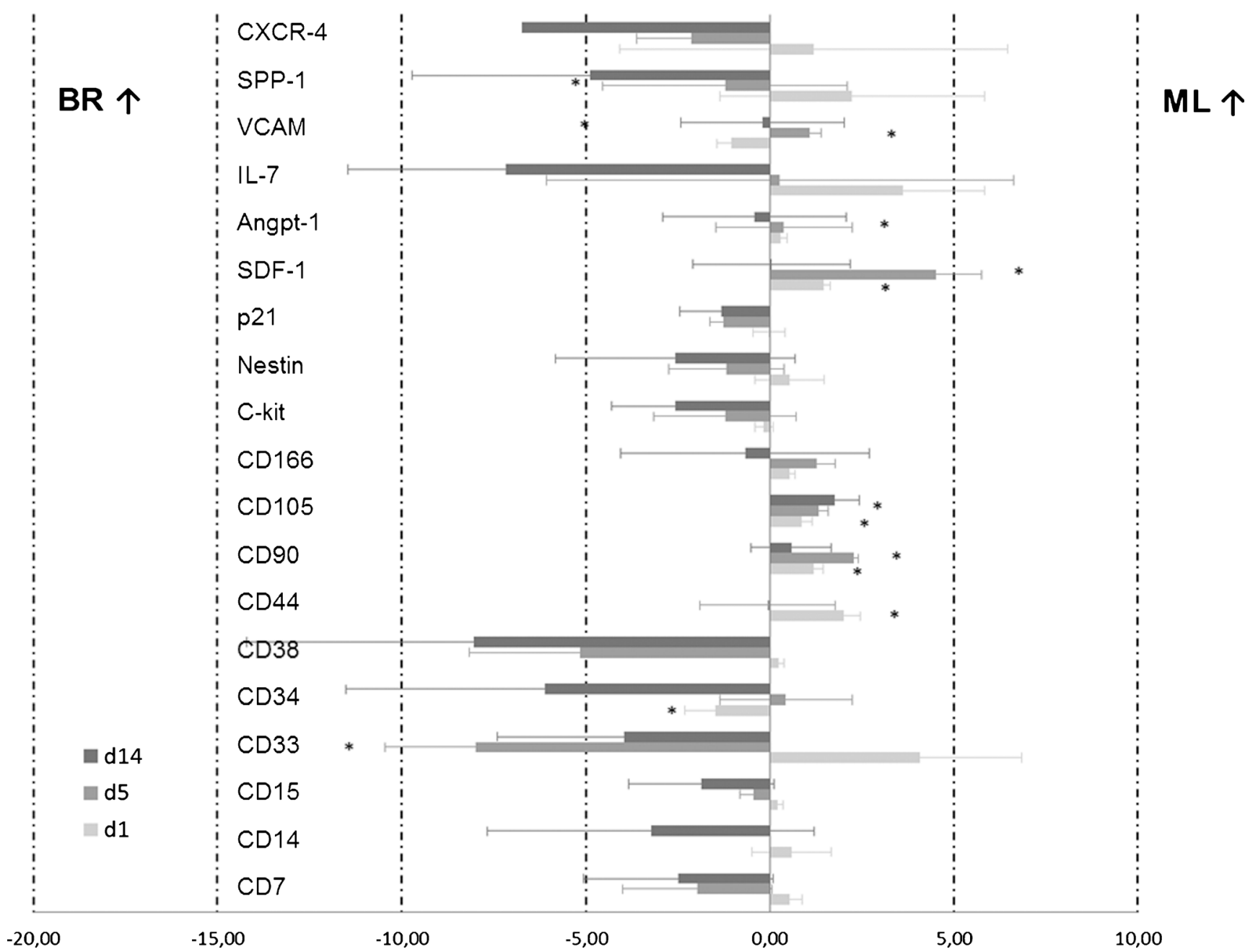

Fig. $2 \Delta \Delta \mathrm{C}_{\mathrm{t}}$ analysis of an HPC/MSC co-culture under superfusion conditions $(400 \mu \mathrm{l} / \mathrm{min})$ in a $3^{\mathrm{D}}$-KITChip-containing bioreactor. Bars pointing to the left indicate relative higher expression in the bioreactor
$(B R)$, whereas bars pointing to the right indicate relative higher expression in the monolayer $(M L)$ setup after 1, 5 and 14 days of HPC/MSC coculture. *Statistically significant as compared with controls 
washing $(5 \times$ TBST $)$ for $10 \mathrm{~min}$, the blots were incubated with the secondary antibody (goat-anti-mouse-peroxidase, A9917; Sigma-Aldrich, St. Louis, MO, USA) at a 1:80,000 dilution in TBST $+10 \%$ non-fat dry milk for $1 \mathrm{~h}$. The membranes were incubated with a mixture of solutions A and B from an enhanced chemiluminescence western blotting detection kit (RPN2132; GE Healthcare, Freiburg, Germany). Finally, the blots were exposed to X-ray films for $30 \mathrm{~s}$ to $2 \mathrm{~min}$ and then developed (Cawomat 2000 IR; Cawo Photochemische Fabrik, Schrobenhausen, Germany).

\section{Wide-field and confocal laser scanning microscopy}

KITChips were seeded with a mixture of MSCs and HPCs (typically 300,000 MSCs and 200,000 HPCs per KITChip) after the chips had been coated with collagen I (from rat tail, C-7661; Sigma) overnight. At 1-21 days after seeding, the cells on the KITChip were carefully washed with PBS and subsequently fixed with $4 \%$ PFA for 15 min at room temperature or methanol:acetone (70:30) for $20 \mathrm{~min}$ at $-20{ }^{\circ} \mathrm{C}$, respectively. To stain for intracellular proteins, a permeabilization step with $0.2 \%$ Triton X-100 was performed. Before IF staining, the microcavity array area of the f-chip type was cut out from the whole KITChip with a surgical scalpel for ease of further processing. The following primary antibodies were used for immunofluorescence staining: CD29 (ms; ThermoFisher Scientific), CD34 (rb; Abcam), CD44 (ms; Abcam), vimentin (gp; Progen), $\beta$-catenin (rb; Sigma), N-cadherin (ms; Sigma), Nestin (rb; MerckMillipore), SDF-1 (rb; AbD Serotec) and CXCR4 (ms; Abcam). The KITChip was incubated with 100-200 $\mu$ of the primary antibody solution for $1 \mathrm{~h}$ and then washed in PBS three times for $5 \mathrm{~min}$ each. Fluorescently labeled secondary antibody staining was performed by incubation in a 100-200 $\mu \mathrm{l}$ volume for $1 \mathrm{~h}$. After three additional washing steps, nuclear staining was performed with $500 \mu \mathrm{l}$ Hoechst (Hoechst 33342, $1 \mu \mathrm{M}$ ) for $5 \mathrm{~min}$, followed by a final three washes in PBS for $5 \mathrm{~min}$ each. The samples were stored in PBS at $4{ }^{\circ} \mathrm{C}$ until microscopic image acquisition.

Additionally, confocal images were acquired at the Nikon Imaging Center at Heidelberg University with a Nikon C2 Plus confocal laser scanning microscope using a $\times 20$ Plan Apo or a $\times 60$ Plan Apo water immersion objective. For $3 D$ image reconstruction of cells, z-stacks with 40-60 slices were acquired. Further processing and analysis of the images and composition of the image figures were performed with ImageJ and Photoshop, respectively.

\section{Statistics}

All experiments were performed at least three times unless otherwise indicated. The Mann-Whitney $U$ test was performed at the significance level 2alpha $=0.05$.

\section{Results and discussion}

\section{Real-time RT-PCR}

We analyzed the expression patterns of selected hematopoietic and mesenchymal stromal cell markers, as well as other markers that may indicate differentiation of the HPCs into the lymphoid and myeloid lineages, after 1, 5 and 14 days in culture. As shown in Fig. 2, a higher expression of CD34 as an hematopoietic progenitor cell marker was found in 3D bioreactor culture, as compared to $2 \mathrm{D}$ monolayer co-culture. It is known that human $\mathrm{CD} 34+$ cells are a heterogeneous cell population but in the clinical setting CD34+ stem cell content in mobilized peripheral blood product remains the most important parameter of graft quality, as it is the only recognized predictor of stable hematopoietic engraftment after stem cell transplantation (Mohty et al. 2014; Siena et al. 2000). However, at the same time a quantitatively higher expression of CD38 was measured in the bioreactor culture, which in a

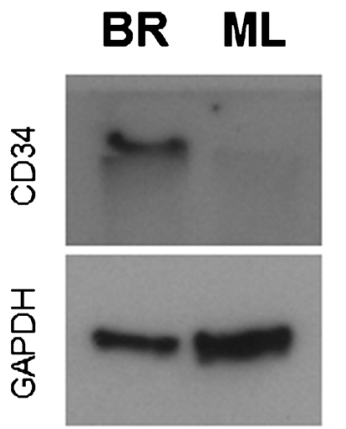

$a^{\prime}$

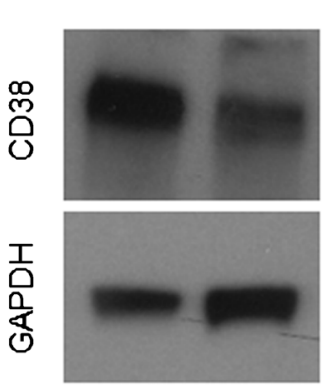

$a^{\prime \prime}$

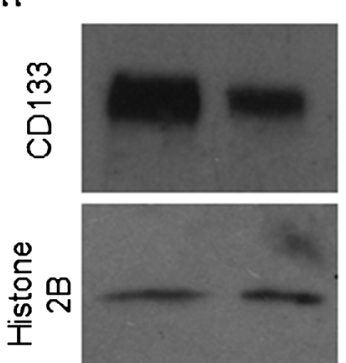

b
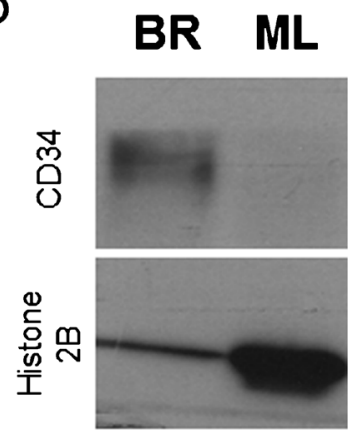

$b^{\prime}$

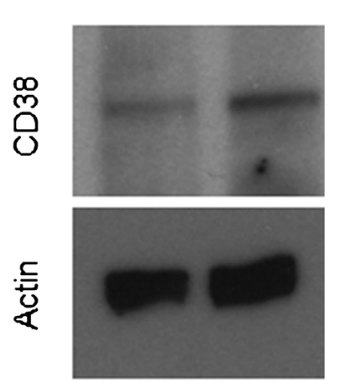

$b^{6}$

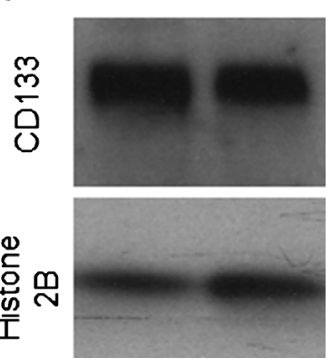

Fig. 3 Western blot analysis of the expression of CD34, CD38, CD133 and GAPDH, actin, or histone 2B. Monolayer and bioreactor samples were lysed after 5 days (a, a', a") and 14 days $(\mathbf{b}, \mathbf{b}, \mathbf{b}$ "), respectively and subjected to western blot analysis 
contrast indicates differentiation of very primitive $\left(\mathrm{CD} 34^{+} /\right.$ $\mathrm{CD}^{-} 8^{-}$) hematopoietic stem cells. We hypothesize that the HPC population is divided into at least two subpopulations, one of which expresses CD34 in bioreactor culture, indicating stem cell maintenance, whereas the other subpopulation shows increased CD38 expression, indicating the loss of stem cell characteristics. This is consistent with reports that increased expression of CD7, CD14, CD15 and CD38 may indicate myeloid or lymphoid differentiation, although CD7 and CD34 coexpression has been reported (Chabannon et al. 1992; Hamblin 2003). However, the expression of predominantly stromal markers, such as CD90, CD105 (not exclusively present on MSC but both included in the MSC marker-panel proposed by the ISCT; Dominici et al. 2006) and Nestin, as well as other stem cell markers such as c-kit, showed a tendency to increase during the culture period. The trend of increasing CXCR4 expression is consistent with the CD34 expression on HPCs, although CXCR4 is also expressed in differentiated cells such as B-lymphocytes (Moepps et al. 1997). The expression of SDF$1 \alpha$, the ligand of CXCR 4 , was significantly decreased at days 5 and 14 , which may consequently trigger the upregulation of CXCR4 over the culture period. Notably, the cyclindependent kinase inhibitor 1 (p21) has been described as a regulator of stem cell pool size (Cheng et al. 2000) and was expressed at slightly higher levels in the 3D environment, which might indicate decreased proliferation in the bioreactor environment. A further characterization via FACS analysis to support this hypothesis is currently not feasible since the complex tissue generated over the cultivation period of 21 days can not be removed from the microcavities without severely damaging the cells. We therefore analyzed the protein expression of the cultured cells by western blot.

\section{Western blot}

The gene expression analysis suggested that CD34 and CD38 were both upregulated in perfused $3 \mathrm{D}$ co-culture. We therefore performed western blots to elucidate the protein expression levels. As shown in Fig. 3, semi-quantitative measurement of CD34 expression after 5 days (Fig. 3a, a', a") and 14 days (Fig. 3b, b', b") was higher in the 3D bioreactor culture than in the monolayer, confirming the PCR-results and supporting the notion that the heterogeneous HPC population presumably is divided into at least two fractions, one of which maintains CD34 expression, whereas the other begins to lose its stem cell characteristics and undergoes rapid cell cycling and proliferation. This result is consistent with previous findings demonstrating that conventional 2D co-culture with MSCs stimulates cell division kinetics of $\mathrm{CD} 34^{+} \mathrm{HPC}$, whereas the colony-forming potential of primitive HPCs is still preserved (Ludwig et al. 2014).

Depending on the source of the stem cells, CD34 may not be expressed on all progenitor cells. An alternative stem cell marker is prominin-1 (CD133), which is expressed on a subpopulation of $\mathrm{CD} 34^{+}$cells as well as on $\mathrm{CD} 34^{-}$progenitor cells derived from various sources including fetal liver and
Fig. 4 Spatial distribution of MSCs and HPCs within the $3^{\mathrm{D}}$ KITchip. a Phase contrast (a) and CLSM images (a') of the 3Dnetwork of MSC and HPC after 21 days in co-culture. F-actin (yellow), cell nuclei (blue, DAPI staining). Scale bars: $200 \mu \mathrm{m}$. b Live cell imaging with phase contrast (b) and fluorescence staining (b') of HPCs marked with CellTracker (green) in the KITChip to demonstrate their spatial distribution within the cell network. Scale bars $50 \mu \mathrm{m}$
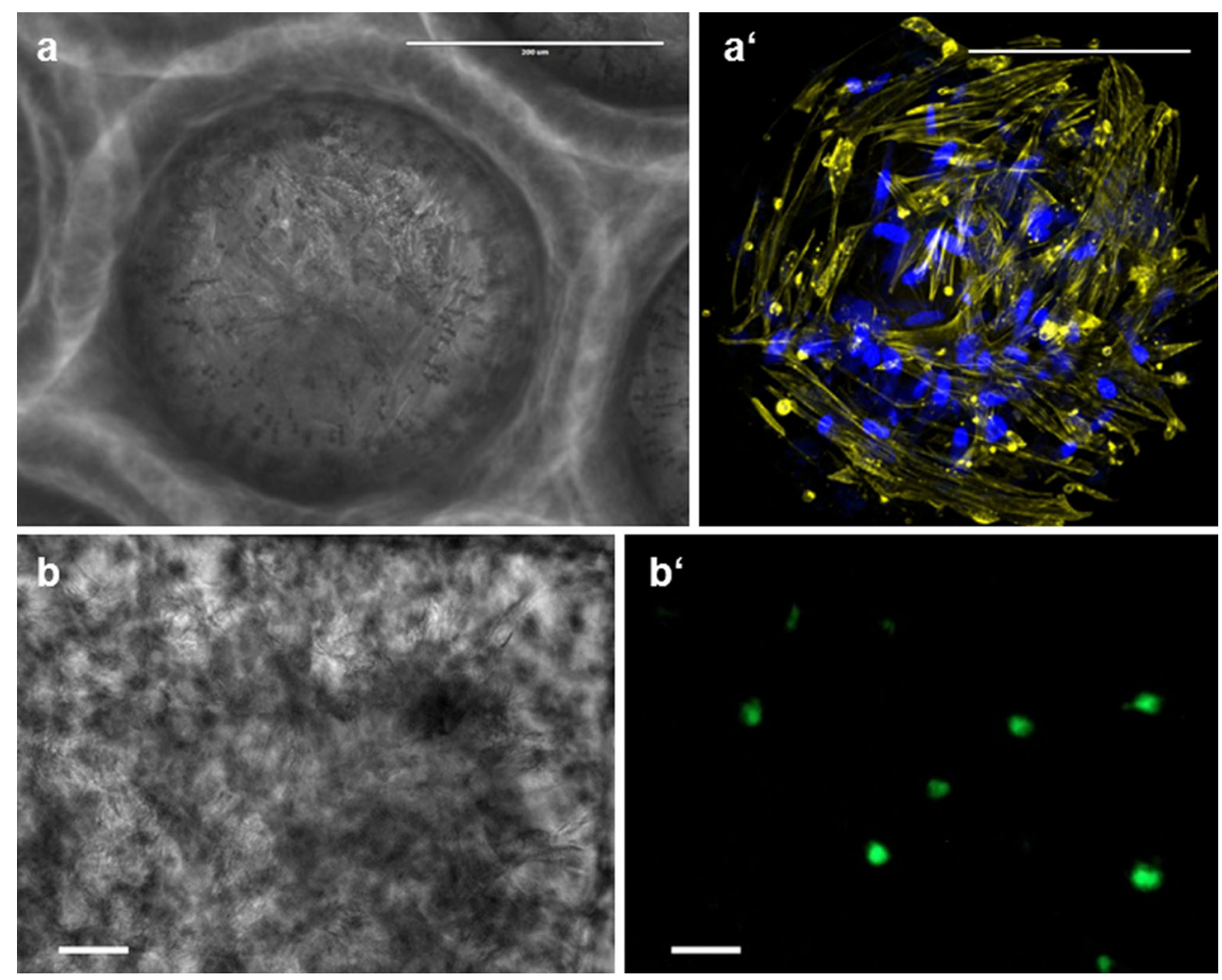
bone marrow, adult bone marrow, cord blood and mobilized peripheral blood (Handgretinger and Kuci 2013). Therefore, we also compared the expression of CD133 in the two types of cell culture. The results shown in Fig. 3a", b" demonstrate that there was a higher level of CD133 expression in the bioreactor culture after 5 days that persisted throughout the culture period of 14 days, although slowly decreasing over time. It has been proposed that CD133-containing membrane microdomains may act as stem cell-specific signal transduction platforms and that their reduction will lead to cellular differentiation (Bauer et al. 2011; Marzesco et al. 2005). Thus, the high expression of CD133 is in line with the results obtained in the colony-forming cell assays that indicates a trend towards stem cell maintenance after 14 days in bioreactor culture.
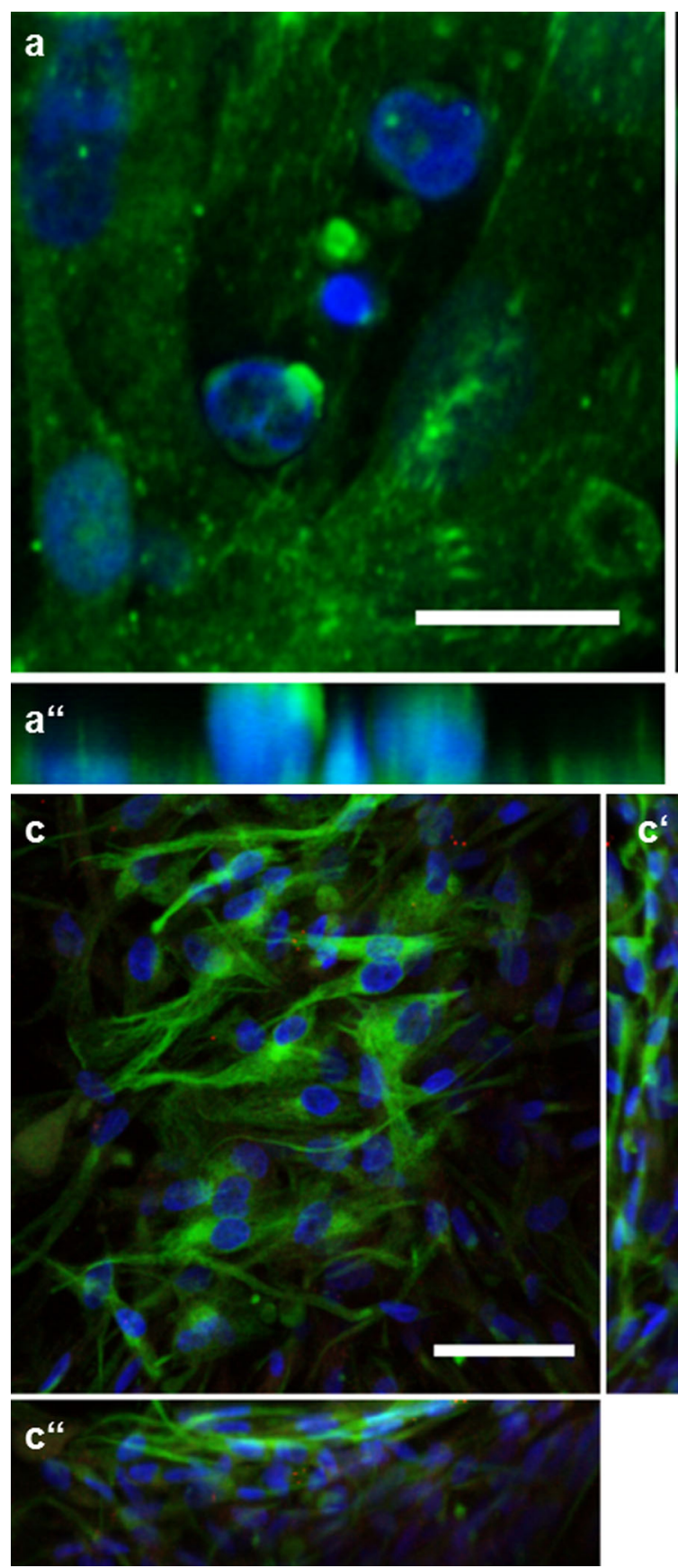

Fig. 5 Immunofluorescence staining of HPCs and MSCs after 1-3 days of co-culture in the $3^{\mathrm{D}}$-KITChip. 3D images were acquired by optical sectioning with a confocal laser scanning microscope. Orthogonal projections in all three dimensions $(\mathrm{x}, \mathrm{y}, \mathrm{z})$ are shown to demonstrate the 3D structure and localization of the MSCs and HPCs in the $3^{\mathrm{D}}$-KITChip. a,
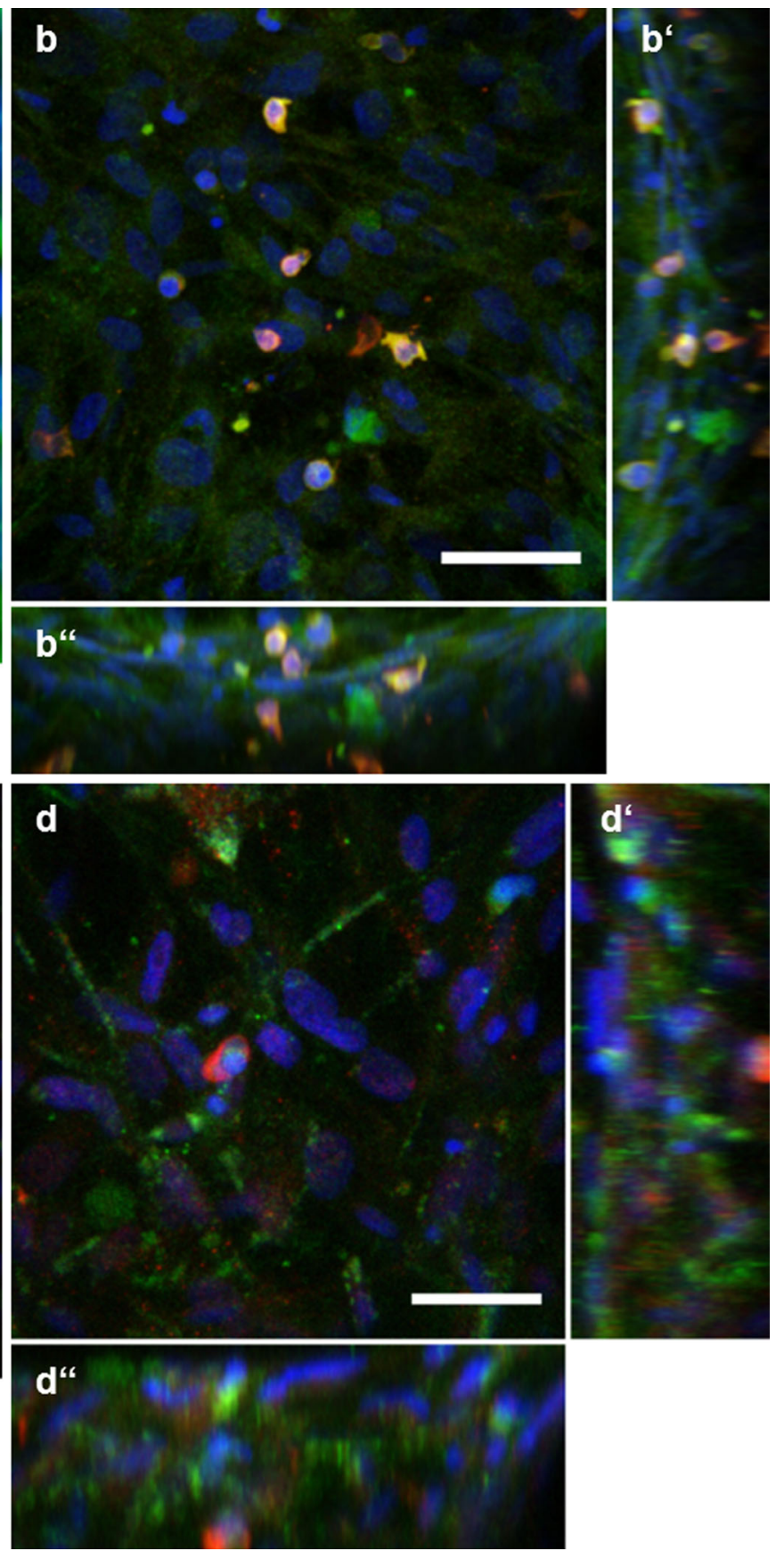

a', a" $\beta$-catenin (green), cell nuclei (blue, DAPI staining). Scale bar $20 \mu \mathrm{m}$. b, b', b" N-cadherin (green), CD34 (red), cell nuclei (blue, DAPI staining). Scale bar $50 \mu \mathrm{m}$. c, c', c" Nestin (green), CD44 (red), cell nuclei (blue, DAPI staining). Scale bar $50 \mu \mathrm{m}$. d, d', d" SDF-1 (green), CXCR4 (red), cell nuclei (blue, DAPI staining). Scale bar $50 \mu \mathrm{m}$. 


\section{Microscopy}

MSCs formed a complex 3D mesh in the microcavities of the $3^{\mathrm{D}}$-KITChip. MSCs within the $3^{\mathrm{D}}$-KITChip could be stably maintained as a monoculture for up to 6 weeks. When HPCs were co-cultured with MSCs, they were evenly distributed inside the MSC mesh in all three dimensions and the HPC population was shown to be interspersed between the MSCs (Figs. 4, 5). To demonstrate the complexity of the MSC/HPC co-culture in single microcavities of the $3^{\mathrm{D}}$-KITChip, we obtained images by optical sectioning with a wide-field microscope as well as with a confocal laser scanning microscope. We stained for a number of cytoskeletal and surface markers (CD34, CD133, CD29, vimentin), intercellular markers for direct cell-cell contacts $(\alpha-/ \beta$-catenin, $N$-cadherin) and HPC/ MSC functional interaction proteins (CXCR4/SDF-1, CD44), which have been examined extensively by us and others in conventional 2D culture systems (Wagner et al. 2005a, c; Walenda et al. 2010; Wuchter et al. 2007, 2014). In the 3D culture system of the $3^{\mathrm{D}}$-KITChip, we found similar patterns of staining as in the monolayer MSC culture or HPC/MSC coculture. Adherens junctions consisting in $\mathrm{N}$-cadherin and $\alpha-/$ $\beta$-catenin were clearly visible at the contact zone between neighboring MSCs but also at the points of contact between HPCs and MSCs (Fig. 5a, a', a”, b, b', b"). As expected, CXCR4 was expressed both on MSCs and HPCs, whereas SDF-1 was only present on MSCs (Fig. 5d, d', d").

Nestin, a recently described marker for MSC populations that contribute to the hematopoietic stem cell niche (MendezFerrer et al. 2010), was also examined. Comparable to observations from monolayer co-culture systems, in the 3D context of the $3^{\mathrm{D}}$-KITChip, we detected Nestin-positive MSCs but their percentages varied (typically $5-20 \%$, in some cases up to $50 \%$ ), mainly depending on the donor of the MSCs (Fig. 5c, c', c”).

\section{Colony forming cell assay}

We analyzed the plasticity of cord blood $\mathrm{CD} 34^{+}$cells by performing colony-forming cell assays (CFAs). Freshly isolated HPCs were compared with those recovered from the 2D or 3D cultures (Fig. 6). As a result, freshly isolated cells mainly formed erythrocytic burst-forming units (BFU-E, $57 \%$ ), colony-forming units of granulocytes (CFU-G, $30 \%$ ) and, to a lesser extent, macrophage colony-forming units (CFU$\mathrm{M}, 6 \%$ ), macrophage and granulocyte-macrophage units (CFU-GM, $6 \%$ ), granulocyte colony-forming units with beginning burst-forming units of erythrocytes (CFU-G beg. BFU-E, $1 \%$ ) and colony-forming units of granulocyte-erythrocyte-monocyte-megakaryocyte (CFU-GEMM, $1.7 \%$ ). After 14 days in 2D monolayer co-culture with MSCs, this distribution changed considerably: CFU-G colonies were present at $29 \%$, CFU-GM at $21 \%$, BFU-E at $33 \%$, CFU-E at $2 \%$ and CFU-M at $15 \%$. In comparison, after 14 days of co-culture with MSC in the $3^{\mathrm{D}}$-KITChip, the colony distribution tended to more resemble the initial analysis but these data are semiquantitative and must not be overrated. The CFU-G colonies were present at $29 \%$, CFU-GM at $17 \%$, CFU-G beginning BFU-E at $8 \%$, BFU-E at $46 \%$ and CFU-M at $6 \%$. Both co-culture cell products failed to form any CFU-
Fig. 6 Comparison of colonies formed in the colony-forming cell assay. HPCs were analyzed after 14 days of 2D monolayer $(M L)$ or $3 \mathrm{D}$ bioreactor $(B R)$ co-culture. Freshly isolated HPCs were used as a control $(n=5$ for fresh HPC, $n=2$ for ML or BR co-culture)

\section{Distribution and number of colonies of freshly isolated HPC and HPC after 14 days of ML or BR co-culture}

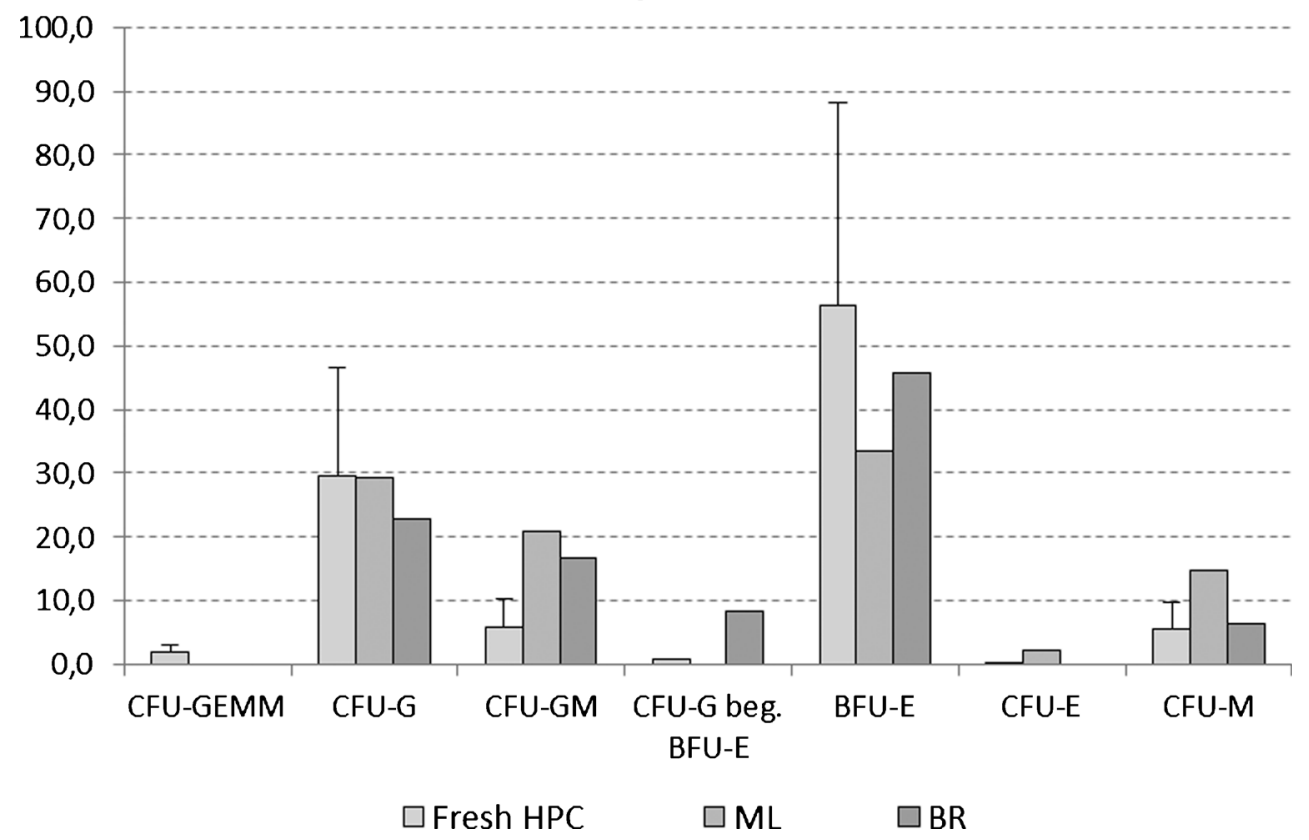


GEMMs. However, the percentage of CFU-GEMMs of freshly isolated HPCs was already low, with only $1.7 \%$. Most probably, only a very small subpopulation of CD34+ cells truly possesses full hematopoietic plasticity potential. As the method of CFA has a relatively limited accuracy, subtle changes of a very small subpopulation might not be adequately reflected. Although the current data of the colony-forming unit capacity are scarce, the CFU-data in conjunction with $\mathrm{RT}^{2}$-PCR and western blot data indicate at least to some extent the maintenance of stem cell properties in the bioreactor culture.

\section{Concluding remarks}

It is known that the stemness of human HPCs can be maintained to a higher degree in co-culture with MSCs, as in suspension culture (Jing et al. 2009; Ludwig et al. 2014; Sharma et al. 2012; Wagner et al. 2005a, 2007a; Walenda et al. 2010). Aiming to simulate the in vivo context more closely, we established an advanced 3D model system of the stem cell niche using human primary HPCs and human bone marrowderived MSCs in co-culture in a perfused microcavity array. All experiments with the $3^{\mathrm{D}}$-KITChip were compared with the present gold standard as a reference: a 2D co-culture setup, consisting in a monolayer of MSCs with HPCs growing on top. We demonstrate that, in the chip-based 3D culture, MSCs grew in several layers and formed a cellular network into which HPCs could fully integrate. As a result, a higher expression of specific stem cell markers was noticed after 14 and 21 days as compared to standard co-culture conditions.

Taken together, we propose that this stem cell niche model provided a more physiological environment for CD $34^{+}$HPCs, leading to the preservation of stem cell properties. Limitations derive from the fact that there exist no generally accepted potency assays that could be applied in this setup. Once methods for the recovery of the MSCs and HPCs from the microcavities have been developed, FACS analysis of the cells will be possible, thus giving a more pronounced insight into the hypothesis that two $\mathrm{CD} 34^{+}$subpopulations have developed into the bioreactor culture. Also, further studies are needed to confirm the stem cell plasticity in serial transplantation experiments, the most plausible proof of stem cell properties.

The versatility of this system could serve various applications in basic research as well as high-throughput drug screening and toxicity testing. Examples for applications in basic research include the identification of soluble factors and cellular determinants responsible for maintaining stemness. In the context of medical research, the first test series are presently being conducted using this system as a platform for the preclinical testing of a variety of substances, including novel reagents for stem cell mobilization and specific growth factors.
Acknowledgments The authors thank Angela Lenze and Anke Diehlmann for isolation and preparation of HPCs and MSCs, as well as David Thiele and Anke Dech for technical assistance. We also thank Siegfried Horn, Jörg Bohn and Hartmut Gutzeit for the construction and manufacturing of the bioreactors and periphery. This work was supported by the German Ministry of Education and Research (BMBF) within the supporting program "Cell Based Regenerative Medicine" (STARTMSC2; funding code 01GN0940 to ADH and PW) and within the collaborative research project "Systems Biology of Erythropoietin" (SBEpo; funding code $0316182 \mathrm{D}$ to $\mathrm{ADH}$ and PW). This work was also supported by the HEiKA Research Alliance (funding to EG and PW) and the German Research Foundation DFG (SFB 873, funding to ADH and PW). The authors also thank the Karlsruhe Nano and Micro Facility (KNMF) for the support of the project.

We acknowledge the Karlsruhe Nano Micro Facility (KNMF, www. kit.edu/knmf ) of KIT for access to instruments at their laboratories and we would like to thank Dr. Matthias Worgull and his team for the manufacturing of the KITChips.

\section{Compliance with ethical standards}

Disclosures The first author and all co-authors confirm that there are no relevant conflicts of interest to disclose, except for the following:

Patrick Wuchter: Honoraria and Membership on Advisory Boards of Sanofi-Aventis. Travel grants from Hexal AG.

Anthony D. Ho: Research funding from and Membership on Advisory Board of Genzyme/Sanofi-Aventis.

\section{References}

Altmann B, Lochner A, Swain M, Kohal RJ, Giselbrecht S, Gottwald E, Steinberg T, Tomakidi P (2014) Differences in morphogenesis of 3D cultured primary human osteoblasts under static and microfluidic growth conditions. Biomaterials 35:3208-3219

Bauer N, Wilsch-Brauninger M, Karbanova J, Fonseca AV, Strauss D, Freund D, Thiele C, Huttner WB, Bornhauser M, Corbeil D (2011) Haematopoietic stem cell differentiation promotes the release of prominin-1/CD133-containing membrane vesicles-a role of the endocytic-exocytic pathway. EMBO Mol Med 3:398-409

Chabannon C, Wood P, Torok-Storb B (1992) Expression of CD7 on normal human myeloid progenitors. J Immunol 149:2110-2113

Cheng T, Rodrigues N, Shen M, Yang Y-G, Dombkowksi D, Sykes M, Scadden DT (2000) Hematopoietic Stem Cell Quiescence Maintained by $\mathrm{p} 21^{\text {cip } 1 / \text { waf1 }}$. Science 287:1804-1808

Christophis C, Taubert I, Meseck GR, Schubert M, Grunze M, Ho AD, Rosenhah A (2011) Shear Stress Regulates Adhesion and Rolling of CD44+ Leukemic and Hematopoietic Progenitor Cells on Hyaluronan. Biophys J 101:585-593

Dang LT, Feric NT, Laschinger C, Chang WY, Zhang B, Wood GA, Stanford WL, Radisic M (2014) Inhibition of apoptosis in human induced pluripotent stem cells during expansion in a defined culture using angiopoietin-1 derived peptide QHREDGS. Biomaterials 35: 7786-7799

de Peppo GM, Vunjak-Novakovic G, Marolt D (2014) Cultivation of human bone-like tissue from pluripotent stem cell-derived osteogenic progenitors in perfusion bioreactors. Methods Mol Biol 1202: 173-184

Dexter TM, Laijtha LG (1975) Proliferation of hemopoietic stem cells and development of potentially leukemic cells in vitro. Bibl Haematol 1975 Oct (43):1-5 
Dexter TM, Allen TD, Lajtha LG (1976) Conditions controlling the proliferation of haematopoietic stem cells in vitro. J Cell Physiol 91: 335-344

Dominici M, Le Blanc K, Mueller I, Slaper-Cortenbach I, Marini F, Krause D, Deans R, Keating A, Prockop D, Horwitz E (2006) Minimal criteria for defining multipotent mesenchymal stromal cells. Int Soc Cell Ther Pos Statement Cytotherapy 8:315-317

Ehninger A, Trumpp A (2011) The bone marrow stem cell niche grows up: mesenchymal stem cells and macrophages move in. J Exp Med 208:421-428

Giselbrecht S, Gietzelt T, Gottwald E, Guber A, Trautmann C, Truckenmüller R, Weibezahn K-F (2004) Microthermoforming as a novel technique for manufacturing scaffolds in tissue engineering. IEE Proc Nanobiotechnol 151:151-157

Giselbrecht S, Gietzelt T, Gottwald E, Trautmann C, Truckenmüller R, Weibezahn K-F, Welle A (2006a) 3D tissue culture substrates produced by microthermoforming of pre-processed polymer films. Biomed Microdevices 8:191-199

Giselbrecht S, Gietzelt T, Gottwald E, Trautmann C, Truckenmüller R, Weibezahn K-F, Welle A (2006b) 3D tissue culture substrates produced by microthermoforming of pre-processed polymer films. Biomed Microdev 8:191-199

Giselbrecht S, Gottwald, E., Truckenmüller, R., Trautmann, C., Welle, A., Guber, A., Saile, V., Gietzelt, T., Weibezahn, K.-F. (2008) Microfabrication of chip-sized scaffolds for the three-dimensional cell cultivation J Vis Exp 15:e699

Gottwald E, Giselbrecht S, Augspurger C, Lahni B, Dambrowsky N, Truckenmüller R, Piotter V, Gietzelt T, Wendt O, Pfleging W, Welle A, Rolletschek A, Wobus AM, Weibezahn K-F (2007a) A chip-based platform for the in vitro generation of tissues in threedimensional organization. Lab Chip 7:777-785

Gottwald E, Giselbrecht S, Lahni B, Hiebl B, Weibezahn K-F (2007b) Cell Chip-basierte Bioreaktoren für die extrakorporale Organunterstützung. Galvanotechnik 4:974-978

Gottwald E. LB, Thiele D., Giselbrecht S., Welle A., Weibezahn K.F. (2008) Chip-based three-dimensional cell culture in perfused micro-bioreactors. J Vis Exp 15:e564

Hamblin TJ (2003) CD38: what is it good for? Blood 102:1939-1940

Handgretinger R, Kuci S (2013) CD133-Positive Hematopoietic Stem Cells: From Biology to Medicine. Adv Exp Med Biol 777:99-111

Hanke M, Hoffmann I, Christophis C, Schubert M, Hoang VT, ZepedaMoreno A, Baran N, Eckstein V, Wuchter P, Rosenhahn A, Ho AD (2014) Differences between healthy hematopoietic progenitors and leukemia cells with respect to CD44 mediated rolling versus adherence behavior on hyaluronic acid coated surfaces. Biomaterials 35 : 1411-1419

Hunt P, Robertson D, Weiss D, Rennick D, Lee F, Witte ON (1987) A single bone marrow-derived stromal cell type supports the in vitro growth of early lymphoid and myeloid cells. Cell 48:997-1007

Jing D, Fonseca AV, Alakel N, Fierro FA, Muller K, Bornhauser M, Ehninger G, Corbeil D, Ordemann R (2009) Hematopoietic stem cells in co-culture with mesenchymal stromal cells-modeling the niche compartments in vitro. Haematologica 95:542-550

Jing DH, Fonseca AV, Alakel N, Fierro FA, Muller K, Bornhauser M, Ehninger G, Corbeil D, Ordemann R (2010) Hematopoietic stem cells in co-culture with mesenchymal stromal cells - modeling the niche compartments in vitro. Haematol-Hematol J 95:542-550

Kodama H, Hagiwara H, Sudo H, Amagai Y, Yokota T, Arai N, Kitamura Y (1986) MC3T3-G2/PA6 preadipocytes support in vitro proliferation of hemopoietic stem cells through a mechanism different from that of interleukin 3. J Cell Physiol 129:20-26

Lapidot T, Kollet O (2002) The essential roles of the chemokine SDF-1 and its receptor CXCR4 in human stem cell homing and repopulation of transplanted immune-deficient NOD/SCID and NOD/SCID/ B2m(null) mice. Leukemia 16:1992-2003
Levesque JP, Helwani FM, Winkler IG (2010) The endosteal 'osteoblastic' niche and its role in hematopoietic stem cell homing and mobilization. Leukemia 24:1979-1992

Liu M, Liu N, Zang R, Li Y, Yang ST (2013) Engineering stem cell niches in bioreactors. World J Stem Cell 5:124-135

Ludwig A, Saffrich R, Eckstein V, Bruckner T, Wagner W, Ho AD, Wuchter P (2014) Functional potentials of human hematopoietic progenitor cells are maintained by mesenchymal stromal cells and not impaired by plerixafor. Cytotherapy 16:111-121

Marzesco AM, Janich P, Wilsch-Brauninger M, Dubreuil V, Langenfeld K, Corbeil D, Huttner WB (2005) Release of extracellular membrane particles carrying the stem cell marker prominin-1 (CD133) from neural progenitors and other epithelial cells. J Cell Sci 118: 2849-2858

Mendez-Ferrer S, Michurina TV, Ferraro F, Mazloom AR, Macarthur BD, Lira SA, Scadden DT, Ma'ayan A, Enikolopov GN, Frenette PS (2010) Mesenchymal and haematopoietic stem cells form a unique bone marrow niche. Nature 466:829-834

Moepps B, Frodl R, Rodewald HR, Baggiolini M, Gierschik P (1997) Two murine homologues of the human chemokine receptor CXCR4 mediating stromal cell-derived factor 1alpha activation of Gi2 are differentially expressed in vivo. Eur J Immunol 27:2102-2112

Mohty M, Hubel K, Kroger N, Aljurf M, Apperley J, Basak GW, Bazarbachi A, Douglas K, Gabriel I, Garderet L, Geraldes C, Jaksic O, Kattan MW, Koristek Z, Lanza F, Lemoli RM, Mendeleeva L, Mikala G, Mikhailova N, Nagler A, Schouten HC, Selleslag D, Suciu S, Sureda A, Worel N, Wuchter P, Chabannon C, Duarte RF (2014) Autologous haematopoietic stem cell mobilisation in multiple myeloma and lymphoma patients: a position statement from the European Group for Blood and Marrow Transplantation. Bone Marrow Transplant 49:865-872

O'Neill JD, Freytes DO, Anandappa AJ, Oliver JA, Vunjak-Novakovic GV (2013) The regulation of growth and metabolism of kidney stem cells with regional specificity using extracellular matrix derived from kidney. Biomaterials 34:9830-9841

Rieke M, Gottwald E, Weibezahn K-F, Layer PG (2008) Tissue reconstruction in 3D-spheroids from rodent retina in a motion-free, bioreactor-based microstructure. Lab Chip 8:1570-1579

Schajnovitz A, Itkin T, D'Uva G, Kalinkovich A, Golan K, Ludin A, Cohen D, Shulman Z, Avigdor A, Nagler A, Kollet O, Seger R, Lapidot T (2011) CXCL12 secretion by bone marrow stromal cells is dependent on cell contact and mediated by connexin- 43 and connexin-45 gap junctions. Nat Immunol 12:391-398

Sharma MB, Limaye LS, Kale VP (2012) Mimicking the functional hematopoietic stem cell niche in vitro: recapitulation of marrow physiology by hydrogel-based three-dimensional cultures of mesenchymal stromal cells. Haematologica 97:651-660

Siena S, Schiavo R, Pedrazzoli P, Carlo-Stella C (2000) Therapeutic relevance of CD34 cell dose in blood cell transplantation for cancer therapy. J Clin Oncol 18:1360-1377

Spiller KL, Nassiri S, Witherel CE, Anfang RR, Ng J, Nakazawa KR, Yu T, Vunjak-Novakovic G (2015) Sequential delivery of immunomodulatory cytokines to facilitate the M1-to-M2 transition of macrophages and enhance vascularization of bone scaffolds. Biomaterials 37:194-207

Truckenmüller R, Giselbrecht S, van Bitterswijk C, Dambrowsky N, Gottwald E, Mappes T, Rolletschek A, Saile V, Trautmann C, Weibezahn K-F (2008) Flexible fluidic microchips based on thermoformed and locally modified thin polymer films. Lab Chip 8:1570-1579

Truckenmuller R, Giselbrecht S, Rivron N, Gottwald E, Saile V, van den Berg A, Wessling M, van Blitterswijk C (2011) Thermoforming of film-based biomedical microdevices. Adv Mater 23:1311-1329

Tsai S, Emerson SG, Sieff CA, Nathan DG (1986) Isolation of a human stromal cell strain secreting hemopoietic growth factors. J Cell Physiol 127:137-145 
Wagner W, Saffrich R, Wirkner U, Eckstein V, Blake J, Ansorge A, Schwager C, Wein F, Miesala K, Ansorge W, Ho AD (2005a) Hematopoietic progenitor cells and cellular microenvironment: behavioral and molecular changes upon interaction. Stem Cells 23: $1180-1191$

Wagner W, Wein F, Seckinger A, Frankhauser M, Wirkner U, Krause U, Blake J, Schwager C, Eckstein V, Ansorge W, Ho AD (2005b) Comparative characteristics of mesenchymal stem cells from human bone marrow, adipose tissue, and umbilical cord blood. Exp Hematol 33:1402-1416

Wagner W, Roderburg C, Wein F, Diehlmann A, Frankhauser M, Schubert R, Eckstein V, Ho AD (2007a) Molecular and secretory profiles of human mesenchymal stromal cells and their abilities to maintain primitive hematopoietic progenitors. Stem Cells 25:26382647

Wagner W, Wein F, Roderburg C, Saffrich R, Faber A, Krause U, Schubert M, Benes V, Eckstein V, Maul H, Ho AD (2007b) Adhesion of hematopoietic progenitor cells to human mesenchymal stem cells as a model for cell-cell interaction. Exp Hematol 35:314 325

Wagner W, Wein F, Roderburg C, Saffrich R, Faber A, Krause U, Schubert M, Benes V, Eckstein V, Maul H, Ho AD (2007c) Adhesion of hematopoietic progenitor cells to human mesenchymal stem cells as a model for cell-cell interaction. Exp Hematol 35:314 325
Walenda T, Bork S, Horn P, Wein F, Saffrich R, Diehlmann A, Eckstein V, Ho AD, Wagner W (2010) Co-culture with mesenchymal stromal cells increases proliferation and maintenance of haematopoietic progenitor cells. J Cell Mol Med 14:337-350

Wein F, Pietsch L, Saffrich R, Wuchter P, Walenda T, Bork S, Horn P, Diehlmann A, Eckstein V, Ho AD, Wagner W (2010) N-cadherin is expressed on human hematopoietic progenitor cells and mediates interaction with human mesenchymal stromal cells. Stem Cell Res 4:129-139

Whitlock CA, Tidmarsh GF, Muller-Sieburg C, Weissman IL (1987) Bone marrow stromal cell lines with lymphopoietic activity express high levels of a pre-B neoplasia-associated molecule. Cell 48:10091021

Wuchter P, Boda-Heggemann J, Straub BK, Grund C, Kuhn C, Krause U, Seckinger A, Peitsch WK, Spring H, Ho AD, Franke WW (2007) Processus and recessus adhaerentes: giant adherens cell junction systems connect and attract human mesenchymal stem cells. Cell Tissue Res 328:499-514

Wuchter P, Leinweber C, Saffrich R, Hanke M, Eckstein V, Ho AD, Grunze M, Rosenhahn A (2014) Plerixafor induces the rapid and transient release of stromal cell-derived factor-1 alpha from human mesenchymal stromal cells and influences the migration behavior of human hematopoietic progenitor cells. Cell Tissue Res 355:315-326 